\section{David O. Davis}

D avid Oliver Davis, MD, Past President of the American Society of Neuroradiology (ASNR), died at his home in McLean, Virginia, on November 29, 2016, after a long battle with Parkinson disease. The son of Oliver and Marie (Collignon) Davis, he was born on June 25, 1933, in Danville, Illinois. As a teenager, he was an accomplished hunter, played on the football team, and graduated first in his class at Schlarman High School. He received his undergraduate education at the University of Illinois, Champaign-Urbana, graduating in 1954. Subsequently, he graduated from St. Louis University School of Medicine in 1958. He and his high school sweetheart, Agnes Layden, began a 61-year marriage in Hoopeston, Illinois, on December 26, 1955.

After an internship at the US Public Health Service Hospital in Staten Island and a radiology residency at Columbia Presbyterian Medical Center in New York, he then served a 2-year neuroradiology fellowship with Juan Taveras at the Neurological Institute and remained on the staff. In 1965, when Taveras assumed the Chairmanship of Radiology at the Edward Mallinckrodt Institute of Radiology at Washington University, he invited Davis to accompany him as Director of Neuroradiology. At Mallinckrodt, he established an excellent fellowship program, earned great respect from the Departments of Neurology and Neurosurgery, began significant investigations, and built friendships with neuroradiologists around the country, particularly with Hans Newton at the University of California, San Francisco.

Dave left St. Louis to join the Department of Radiology at the University of Utah and eventually moved to George Washington University, where he was Director of Neuroradiology and subsequently Professor and Chairman of the Department of Radiology. The Davis family lived in the Watergate Apartments for 22 years. His 5 daughters ran a wildly successful hot dog stand in front of the Watergate for 4 summers in the 1970s. Agnes launched a successful real estate enterprise, not only in the DC area but also on Captiva Island in Florida.

A wag once said, "The public memory is six weeks." For this reason, Dave's many contributions to the ASNR and to organized radiology certainly deserve recounting. While he was a Past President of ASNR, his most important service to the society was as a "senior statesman," representing the Society as it pursued some of its most important issues during the turbulent years from 1980 to 2000. Facing the Society in those years were competition from nonfellowship-trained radiologists and other physicians to interpret neuroradiology studies and the question of whether neuroradiologists should train non-neuroradiologists in the performance of cerebral angiography and interventional neuroradiology. These issues resulted in a push to create a Certificate of Added Qualification (CAQ) in neuroradiology. This met with considerable opposition within the ASNR, within organized radiology, within various specialty-certifying boards, and the American Hospital Association.

Dr Davis was a major activist in lobbying for the CAQ in neuroradiology. Time after time, he presented what was an unpopular argument before the Society, at the Radiology Summit, and before a hostile American Board of Radiology, but his diplomacy and

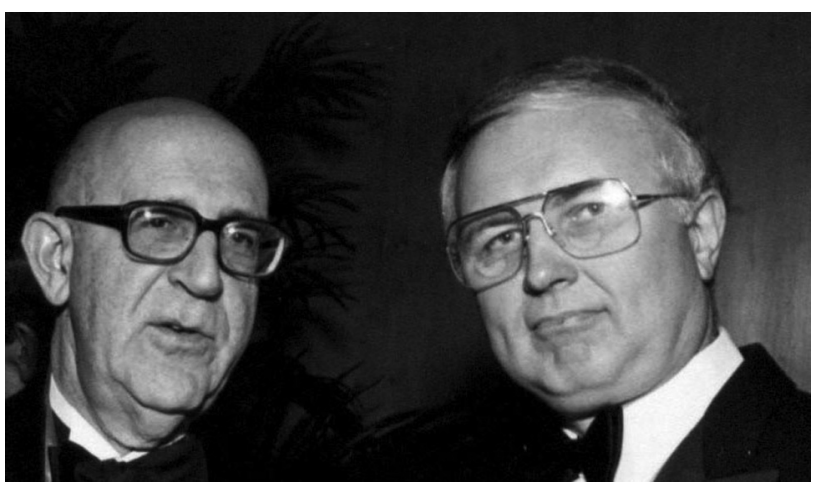

ASNR Founding President Juan M. Taveras (left) with David O. Davis.

personal integrity were major factors in achieving that goal. Despite his unpopular cause, he was elected to the Board of Chancellors of the American College of Radiology and was an effective voice for neuroradiology in that body. Being respected as a radiologist and being personally well-liked were major factors in the success of the ASNR in establishing a CAQ.

The fledgling American Journal of Neuroradiology (AJNR) was originally owned and published by the American Roentgen Ray Society (ARRS). As a member of the Executive Council of the ARRS, he was an important liaison between the ARRS and the AJNR. As Chair of the ASNR Publications Committee, he handled the delicate negotiations between the ARRS and the ASNR, which resulted in the successful venture of the AJNR into self-publication. He also oversaw the subsequent development of the Journal with his wise fiscal and managerial expertise.

In my years on the Executive Committee and as Editor-inChief of AJNR, whenever a thorny issue of turf arose, the decision was usually to "let Dave handle it." He never refused a mandate, often accepting challenges in which he differed with the views of the Society, but which he pursued because he felt they would benefit the Society and improve patient care.

There is a devoted cadre of ASNR members who trained under Dave. They recall his devotion to developing our specialty in its early days with innovations such as the "Davis rake" and the "Davis needle." He was a stickler for impeccable radiographic technique and safe performance of invasive procedures. No matter where he practiced, clinicians sought his opinion above those of all others because of his astute observations and his innovative ideas and because he delivered them all with confidence and a fine sense of humor.

There were few members of ASNR with greater personal and professional respect than Dave. He would never seek an honor, and his curriculum vitae was pried from him with great resistance to nominate him for the ASNR Gold Medal, which was awarded to him in 2002. Beginning in 2000, illness crept up insidiously, and George Washington University awarded him emeritus status in 2010.

Devoted to his family, he instilled in his 5 daughters a love of travel. He treated them and their children to serious tennis lessons, skiing, and road trips throughout the Western United States and taught them to throw a football with a perfect spiral. Nineteen grandchildren arrived between 1987 and 2001. Many grandkids only knew that Grandpa was "ill" with what was eventually diag- 
nosed as Parkinson disease. Nevertheless, he and Agnes took nearly the "whole pack" (27) on family vacations, touring Ireland in 2006 and Nicaragua in 2012, and annually hosted the family in Captiva at Christmas time.

In May 2015, Dave and Agnes moved into assisted living in McLean, Virginia, where Dr Davis died on November 29, 2016. A mass of Christian burial was celebrated at Holy Trinity Catholic Church in Georgetown, where 4 of his 5 daughters had been married. Before the mass, Dr Michael Newman, his friend and personal physician eulogized Dave as "A Midwesterner with a huge presence who ... held himself to the highest of standards and expected no less from others.... He was smart, very smart and intuitive whether interviewing someone to recruit, mulling over a clinical problem, or designing a research project with a 'why not?' approach. He was a leader at George Washington Medical Center and a leader in professional societies and organizations of Radiology and Neuroradiology. His manner was direct, honest, and supportive often by using sardonic wit to make a point. He was always respectful and, when appropriate, critical in an instructive manner and never demeaning."

Neuroradiology has lost a leader whose impact on the specialty will be felt for many years. Those of us fortunate enough to have known him personally have lost a wonderful friend.

M. Huckman

http://dx.doi.org/10.3174/ajnr.A5114 